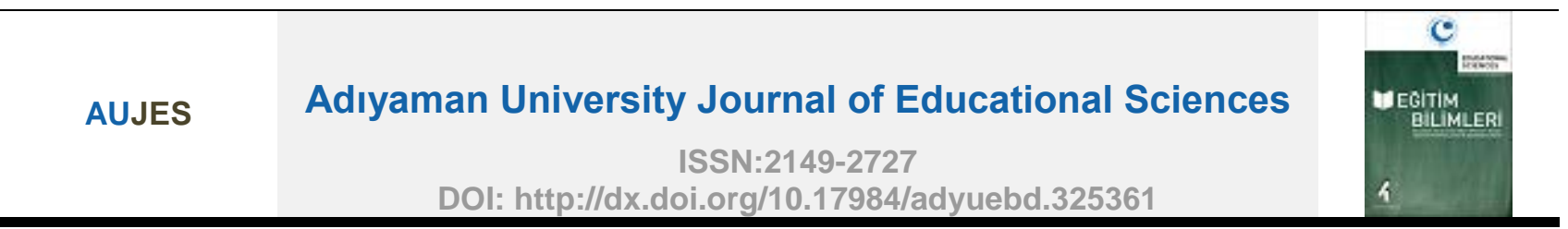

\title{
Evaluation of the Usability of Concept Maps When Teaching the Subject of Rational Numbers
}

\author{
Tamer KUTLUCA ${ }^{1 *}$, Muhammet DÖNER ${ }^{2}$, Veysel BUTAKIN ${ }^{3}$
}

${ }^{1,3}$ Dicle University, Faculty of Education, Turkey

${ }^{2}$ Dicle University, Graduate School of Education Sciences, Turkey

\begin{tabular}{l} 
ARTICLE INFO \\
\hline Article History: \\
Received \\
18.06.2016 \\
Received in revised \\
form 26.12 .2016 \\
Accepted \\
02.01.02017 \\
Available online \\
30.06.2017
\end{tabular}

\begin{abstract}
The objective of this study is to evaluate the teachers' and students' thoughts on the usability of concept maps when teaching the subject of rational numbers. As it was attempted to analyze this issue deeply in this research, "the qualitative research approach" was adopted. The study group consisted of 23 students of seventh grade and one mathematics teacher. In this study, descriptive analysis method was used in order to reveal the teachers' and students' thoughts. Concept map activities were applied on the students, and a survey consisting of 5 open-ended questions was conducted in order to find out the students' thoughts on these activities and the relevant teaching method. Moreover, a semi-structured interview was conducted with the teacher. When the teachers' opinion on the usability of concept maps on the subject of rational numbers was evaluated, it was determined that; concept maps present a learning environment different from the traditional learning environment, that these maps have an instructive characteristic, that they help meaningful learning and that they make the lesson more enjoyable.
\end{abstract}

Keywords:

(C) 2017 AUJES. All rights reserved Concept Map, Mathematics Teaching, Rational Numbers

\section{Extended Abstract}

\section{Purpose}

Many researches, in which the positive effects of mind maps were put forward, have been carried out. There are many researches available on the effects that are improving success. In several researches, studies have been carried out on whether mind maps develop "the problem-solving skill", on "conceptual changes", on "determining the misconceptions", on "perception levels", on "using mind maps as evaluation instruments", and on "the development of critical thinking skills". When the studies previously carried out are analyzed; it can be seen that the experimental and quantitative studies about the effects

\footnotetext{
${ }^{*}$ Corresponding author's address: Dicle University, Faculty of Education, Department of Elementary School Mathematics Education, Diyarbakır

e-mail: tkutluca@dicle.edu.tr
} 
of mind maps on the learning process, are predominant. However, in literature, there isn't any research in which mind maps are designed, and teachers' and students' thoughts are evaluated. The purpose of this study, is to evaluate the teacher' and students' thoughts on the applicability of concept maps when teaching the subject of rational numbers.

\section{Method}

Because an attempt was made to analyze an issue deeply in this research, "the qualitative research approach" was adopted. Within this framework, it was attempted to describe the teachers' and students' thoughts on the applicability of concept maps created for teaching the subject of rational numbers in math class. The study group consisted of 23 students of seventh grade and one mathematics teacher. In this study, descriptive analysis method was used in order to reveal the teachers' and students' thoughts. Concept map activities were applied on the students, and a survey consisting of 5 open-ended questions was conducted in order to find out the students' thoughts on these activities and the relevant teaching method. Moreover, a semi-structured interview was conducted with the teacher. The data collected in order to determine the teachers' and students' thoughts, were analyzed by descriptive analysis method. In this context, the data collected were analyzed, categories were created in accordance with the research objective, and several samples were encoded, and then presented with citations.

\section{Results}

The teacher thinks that Concept Maps would come in quite useful. He made the lesson more attractive for the students. He told that it would be useful to add Concept Maps to the lesson, that these maps would be an appropriate material for math lesson, and that it would make learning permanent. It was determined that the students had positive opinions, and that they rather liked the activites that were based on interpretation. The most serious difficulties that the students had in the previous lessons were; being unable to perceive, understand, and regarding the lesson as pointless. It has been determined that the problems the students had on perception and understanding, were solved thanks to these concept maps.

\section{Discussion and Conclusion}

When the teacher' opinion on the applicability of concept maps on the subject of rational numbers was evaluated, it was determined that; concept maps present a learning environment different from the traditional learning environment, that these maps have an instructive characteristic, that they help meaningful learning, that they make learning permanent, and that they make the lesson more enjoyable. Similarly, in consequence of his study, Tuluk (2015) proved that concept map is an effective technique which can be used to 
teach a lesson at the level of bachelor degree, to control a learning process, to determine the misconceptions, and to get to know the students. The other result obtained from our research is that; concept maps are appropriate materials for math lesson, that they are useful for determining the misconceptions. When the students' opinions were taken into consideration at the end of the study, it was determined that the students had positive opinion on the learning process conducted by means of concept maps. However, while the majority of the students were of the opinion that the learning environment of this type would be of much help for them; it was observed that a few students, who had displayed a high performance in a lesson thought by the old system, showed a low performance in this lesson and got illtempered. The main reason for this is that; more burdens fell on high-level students because of the intra-group level difference, and because the others were unable to adapt to the new class environment. As a matter of fact, Çimer \& Çimer (2002) expressed that the majority of students found creating concept maps boring, and they stated that it was not enjoyable. This outcome obtained from our research, conflicts with the study of Çimer \& Çimer (2002) from this aspect. 


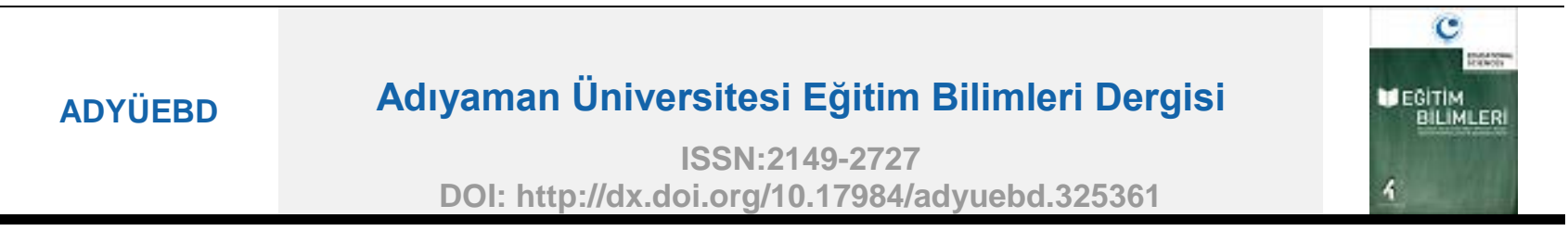

\title{
Rasyonel Sayılar Konusunun Öğretiminde Kavram Haritasının
}

\section{Kullanılabilirliğinin Değerlendirilmesi}

\author{
Tamer KUTLUCA ${ }^{1 *}$, Muhammet DÖNER ${ }^{2}$, Veysel BUTAKIN ${ }^{3}$
}

${ }^{1,3}$ Dicle Üniversitesi, Eğitim Fakültesi, Türkiye

${ }^{2}$ Dicle Üniversitesi, Eğitim Bilimleri Enstitüsü, Türkiye

MAKALE BÍLGI

Makale Tarihçesi:

Alındı 18.06.2016

Düzeltilmiş hali

alındı 26.12.2016

Kabul edildi

02.01.2017

Çevrimiçi yayınlandı 30.06.2017

\section{ÖZET}

Bu çalışmanın amacı Rasyonel sayılar konusunun öğretiminde kavram haritası kullanımı hakkında öğretmen ve öğrencilerin görüşlerini değerlendirmektir. Bu araştırmada, bir durum derinlemesine incelenmeye çalışıldığından "Nitel araştırma yaklaşımı" benimsenmiştir. Bu çerçevede matematik öğretiminde rasyonel sayılar konusunun öğretiminde oluşturulan kavram haritalarının kullanılabilirliğine ilişkin olarak öğretmen ve öğrencilerin görüşleri betimlenmeye çalışılmıştır. Çalışma grubu 23 ortaokul yedinci sınıf öğrencisi ve bir ortaokul matematik öğretmeninden oluşmaktadır. Bu çalışmada öğretmen ve öğrencilerin görüşlerini ortaya çıkarmak için betimsel analiz yönteminden faydalanılmıştır. Hazırlanan kavram haritaları etkinlikleri öğrencilere uygulanmış olup etkinliklere ve gerçekleştirilen öğrenime ilişkin öğrencilerin görüşlerini belirlemek amacıyla 5 adet açık uçlu sorudan oluşan görüşme formu uygulanmıştır. Ayrıca ders öğretmeni ile yarı yapılandırılmış mülakat yapılmıştır. Kavram haritasının rasyonel sayılar konusunun öğretiminde kullanımı hakkında öğretmen görüşü değerlendirildiğinde, kavram haritalarının öğrencilerin kendi bilgilerini yapılandırmasından dolayı geleneksel ortamdan farklı bir öğrenme ortamı oluşturduğu, öğretici bir özelliğe sahip olduğu, anlamlı öğrenmelerine yardımcı olduğu ve dersi daha eğlenceli bir hale getirdiği görüşünü taşıdığı ortaya çıkmıştır.

(C) 2017 AUJES. Tüm hakları saklıdır

Anahtar Kelimeler:

Kavram Haritası, Matematik Öğretimi, Rasyonel Sayılar

\section{Giriş}

Kavram haritaları, kavramların birbirleriyle ilişkilerini gösteren iki boyutlu bir şema olduğu belirtilmektedir (Kaptan, 1998). Kavram haritaları, 1960'lı yıllarda David Ausebel'in ifade ettiği Anlamlı Öğrenme Teorisinden esinlenmiş, 1970'li yıllarda Novak \& Cornell Üniversitesi mezunu öğrencileri tarafından yürütülen araştırma projesinin bir parçası olarak geliştirilmiştir (Novak \& Gowin, 1984). Kavram haritaları özellikle bilginin zihinde somut ve görsel olarak düzenlenmesinde önemli rol oynar.

\footnotetext{
*Sorumlu yazarın adresi: Dicle Üniversitesi, Eğitim Fakültesi, İlköğretim Matematik Eğitimi Anabilim Dalı, Diyarbakır e-mail: tkutluca@dicle.edu.tr
} 
Çünkü bir öğretim yılı bir ünite ya da bir ders içinde önemli kavramlar arası ilişkileri şematize etmede etkili bir yol olduğu ifade edilmektedir (Kaptan, 1998).

Novak \& Gowin (1984), kavram haritalarının öğrencilerin katılımıyla yapılmasının öğrenmelerinde daha etkili olduğunu savunmaktadır. Zira bu şekildeki aktivite ile öğrencilerin zihnindeki fikirlerle oluşturulan harita ile bir ilişki kurmak zorundadır. Bu şekilde kavramlar arasında bir ilişki kurularak yeni bilgiler oluşturulmaktadır (Novak \& Canas, 2008). Bu bağlamda kavram haritaları, yapılandırmacı yaklaşımın bir sonucu olarak düşünülebilir. Bilgi birtakım alt birimlere bölünerek gösterilebilir. Konu, diğer alt birimlere, bunlar da ana ve yan temalara ve bilginin en küçük yapı taşı olan kavramlara ayrılır. Kavramlar, oluşmasına neden olan ya da olmayan diğer özellikleriyle ele alınabilir (Kaşlı, Aytaç \& Erdur, 2001). 1990'dan beri kavram haritası farklı disiplinlerde yapılan araştırmalarda kullanılmıştır (Kaptan, 1998; Öztürk \& Karayağız, 2006; İngeç, 2008; Huang ve diğ., 2012; Torre, Durning \& Daley, 2013; Tuluk, 2015). Öğrenciler kavram haritasının kullanımında zorlandıkları bilinmektedir. Kavram haritalarının amacı sadece öğrenmeyi kolaylaştırmamakta aynı zamanda öğrenmeyi de etkili kılmaktır. Bu noktadan yola çıkarak kavram haritalarının oluşturulması fikrinin temelinde, "öğrenme, kavramların ilişkilendirilmesi ve kullanılması sırasında gerçekleşir” görüşü yer almaktadır (Boyle, 1997). Kavram haritalarının kalıcı öğrenme sağladığı, öğrenme güçlüğü yaşayan öğrencilere destek olduğu, öğrencilerin farklı yapıları bir bütün şeklinde algılamalarını sağladığı, öğretmene öğrencilerinin sahip olduğu bilgileri gözlemleme ve hangi öğrencilerinin yardıma ihtiyacı olduğunu ayırt etme imkanı sağladığı ve ürün seçki dosyalarının takip edilmesinde daha etkili olduğu vurgulanmaktadır (Anderson- Inman \& Ditson, 1999; Gürbüz, 2006).

Novak \& Gowin (1984) kavram haritalarının, problem çözme ve bildiklerini ortaya koymasında yardımcı olduğunu ifade etmektedir. Kavram haritaları ile ilgili pek çok araştırma yapılmıştır. Özellikle başarıya katkı sağladığı ile ilgili araştırmalar bir hayli fazladır (Altıntaş \& Altıntaş, 2008; Oğraş \& Bozkurt, 2011; Chiou, Tien \& Lee, 2015; Çömek, Akınoğlu, Elmacı \& Gündoğdu, 2016). Bazı araştırmalarda kavram haritalarının "problem çözme becerisini geliştirdiğine" (Hay \& Proctor, 2015), "kavram değişimlere etkisine" (Sellmann, Liefländer \& Bogner, 2015), "kavram yanılgılarının belirlenmesine" (Şen \& Aykutlu, 2008; Tuluk, 2015), "anlama düzeylerine etkisine" (Evrekli, İnel \& Balım, 2012), "değerlendirme aracı olarak kullanılmasına" (Şahin, 2001; Şen \& Aykutlu, 2008) ve "eleştirel düşünme becerilerinin gelişimine" (Atay \& Karabacak, 2012) yönelik çalışmalar yapılmıştır.

Ortaokul öğrencilerine öğretilen rasyonel sayılar konusu, olasılık, oran ve orantı gibi matematik konularının öğretiminde önem teşkil etmekte olduğu bilinmektedir. Doğal sayıların ve tam sayılar ile ilişkilendirilen ve günlük hayatımızın önemli bir parçası olan rasyonel sayılar, kompleks özellikler içeren bir sayı sistemidir. Rasyonel sayıların bu karmaşıklığı, konunun öğretiminde zengin bir içerik oluşturmakla birlikte bazı zorlukları oluşturmaktadır (Durmuş, 2005). Yapılan çalışmalar, rasyonel sayılar (kesirler) konusundaki temel kavramları anlamada ve cebirsel işlem yapmada öğrencilerin zorlandıklarını belirtmektedir (Birgin \& Gürbüz, 
2009). Rasyonel sayıların öğrenciler tarafından anlaşılabilmesiı için ayrıklığın doğal sayılar kümesine ait bir özellik olduğunun ve rasyonel sayıların kesir ve ondalık kesir gösterimlerinin olduğunun kavranması gerekmektedir (Vamvakoussi \& Vosniadou, 2007). Oysaki yapılan çalışmalar doğal sayılar kümesindeki ayrıklık özelliğini rasyonel sayılara genişletmenin, rasyonel sayılar kümesinin yoğunluğunu kavramada sorun teşkil ettiğini belirtmektedir (Merenluoto \& Lehtinen, 2004; Stafylidou \& Vosniadou, 2004; Vamvakoussi \& Vosniadou, 2004). Orhun (2007) ve Gürbüz ve Birgin (2008) farkı öğrenim seviyelerindeki öğrenciler üzerinde yaptıkları araştırmalarda öğrencilerin paydaları eşit olmayan kesirlerin sıralaması, toplanma ve çarpılması, denk kesrin bulunması konularında güçlükler yaşadıklarını belirtmektedir. Diğer taraftan TIMSS'in 1999 yılındaki sonuçları da ülkemizdeki öğrencilerin rasyonel sayıları anlamalarında düşük bir seviyede olduğunu ve diğer ülkelerin öğrencileriyle mukayese edildiğinde daha alt seviyelerde bulunduğunu göstermektedir (EARGED, 2003).

Yapılan araştırmalarda; kavram haritalarının öğrenme sürecine etkileri üzerine nicel çalışmaların özellikle deneysel araştırmaların çoğunlukta olduğu görülmektedir. Ancak literatürde matematik öğretiminde kavram haritaların tasarlanıp, öğretmen ve öğrenci görüşlerinin kullanılabilirliğinin değerlendirildiği araştırmalara rastlanmamaktadır. Bunun yanında öğrencilerin rasyonel sayılar konusundaki temel kavramları anlamada ve cebirsel işlem yapmada zorlandıklarını araştırmalarda ifade edilmektedir. Ancak rasyonel sayılar konusunun kavram haritalarıyla hazırlanıp öğrenci ve öğretmen gözünden değerlendirilmesi yapılan çalışmalar sınırlıık gösterdiğinden bu çalışma önem arz etmektedir. Bu bağlamda bu çalışmanın amacı matematik öğretiminde rasyonel sayılar konusunun öğretiminde kavram haritalarının kullanılabilirliği hakkında öğretmen ve öğrencilerin görüşlerini değerlendirmektir.

\section{Yöntem}

\section{Araştırma Deseni}

$\mathrm{Bu}$ araştırmada bir durum derinlemesine incelenmeye çalışıldığından "Nitel araştırma yaklaşımı" benimsenmiştir. "Nitel araştırma; gözlem, görüşme ve doküman analizi gibi nitel veri toplama yöntemlerinin kullanıldığı, algıların ve olayların doğal ortamda gerçekçi ve bütüncül bir biçimde ortaya konmasına yönelik nitel bir sürecin izlendiği araştırmadır" (Ekiz, 2009). Bu çalışma da davranışlarla ilgili anlayışları tanımlamaya uygun olan nitel araştırma yaklaşımı kapsamında tasarlanmışıı. Bu çerçevede matematik öğretiminde rasyonel sayılar konusunun öğretiminde oluşturulan kavram haritalarının uygulanabilirliğine ilişkin olarak öğretmen ve öğrencilerin görüşleri betimlenmeye çalışılmıştır.

\section{Çalışma Grubu}

Çalışma grubu 2015-2016 Eğitim-Öğretim yılında Doğu Anadolu bölgesinde Bingöl ili Genç İlçesinde bir ortaokulda öğrenim gören 23 ortaokul yedinci sınıf öğrencisi ve bir ortaokul matematik öğretmeninden oluşmaktadır. Araşıırma etiği çerçevesinde öğrencilerin isimleri kullanılmamıştır. Bu nedenle öğrenciler Ö1, Ö2, Ö3......kodlarıly isimlendirilmiştir. 


\section{Ders Öncesi ve Öğrenme Süreci}

Ders öğretmeni ile yapılan ön görüşmede Kavram Haritaları hakkında bilgi verilmiştir. Öğretmenden ders işlenişinin kavram haritaları eşliğinde yapılması ve kavram haritasının öğretime monte edilmesinin oluşturacağı etki hakkında ön görüşü alınmıştır. Ders öğretmeni ile yapılan ön görüşmede öğretmenin kavram haritalarıyla ilgili negatif düşünceleri olduğu görülmüştür. Ders öğretmeni kavram haritalarının ders ortamında uygulanabilirliğinin düşük olduğunu, öğrencilerin bu etkinlikleri yaparken zorlanacaklarını ve bunun da onlarda derse karşı olumsuz tutumlar oluşturacağını düşünmektedir. Bu nedenle kavram haritalarının nasıl kullanılacağı konusu ders öğretmenine anlatılmış olup ders işlenişi araştırmacı tarafından izlenmiştir. Araştırmacı dersin işlenişine müdahale etmeyip sadece işleniş ve gidişatla alakalı notlar tutmuştur. İlk derste Rasyonel Sayılar konusunun tanımlamaları yapılmış ve kavram haritaları üzerinden öğrencilere kavratılmaya çalışılmıştır. Problemler kavram haritası ile hazırlanmıştır. İkinci ders için öğrencilerin tamamını kapsayacak şekilde üçerli gruplar halinde kavram haritasıyla hazırlanmış Konu Değerlendirme Testi verilmiş ve çözmeleri istenmiştir. Öğrencilerin vermiş olduğu cevaplar öğretmen tarafından değerlendirilmiştir. Öğrenme ortamına ilişkin olarak öğrenme ortamından kareler aşağıda Şekil 1'de verilmiştir.
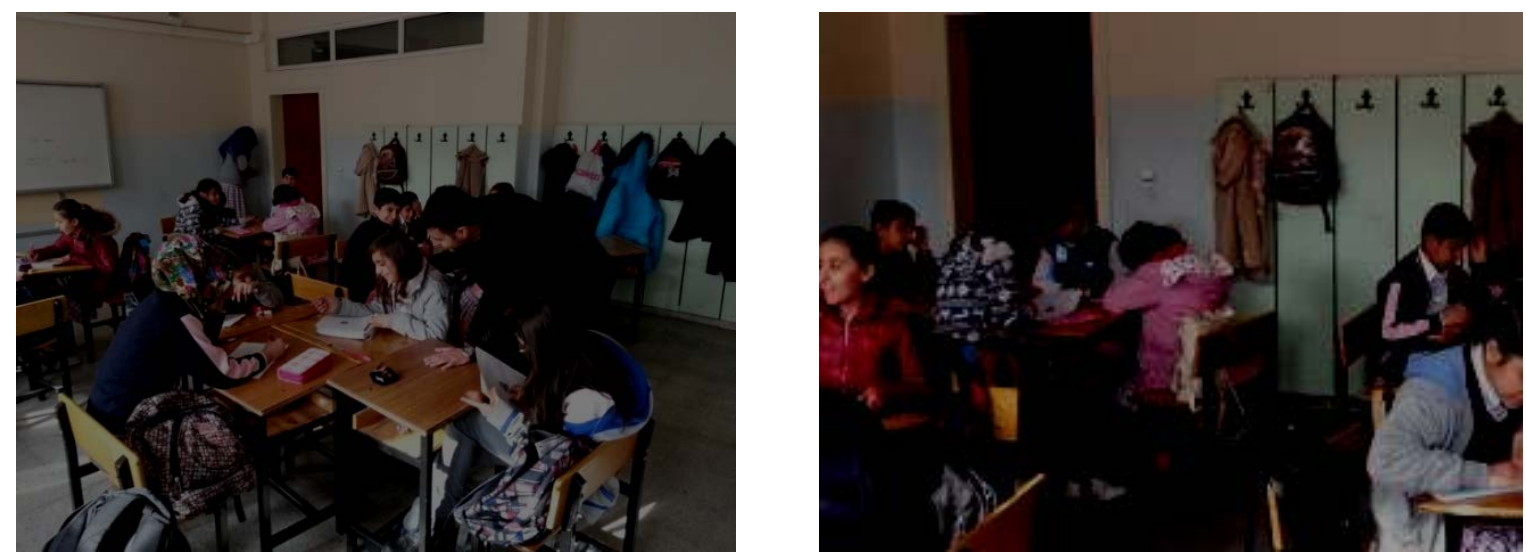

Şekil 1. Öğrenme Ortamından Kesitler

\section{Kavram Haritası Tekniğiyle Hazırlanan Etkinlikler ve İçerikleri}

Rasyonel sayılar konusunda hazırlanmış kavram haritaları incelenmiş olup kavram haritalarını da içeren bir plan hazırlanmıştır. Plan dersin öğretmenine verilmiştir. Öğretmen bu plan doğrultusunda dersi işlemiştir. Hazırlanan etkinliklere "Rasyonel Sayıları Tanıyorum Etkinliği”, "Sıralayabildiklerimizden misiniz? Etkinliği", "Topla-Çıkar Elde Var Rasyonel Sayı Etkinliği”, "Çarp-Böl Anla Etkinliği”, "İşlemlerim Adım Adım Etkinliği” isimleri verilmiştir. Toplam beş etkinlik hazırlanmıştır. Etkinliklerin hazırlanmasında 2 alan eğitimi uzmanı ve 2 matematik öğretmeninin görüşlerinden yararlanılmıştır. 
Uygulanan Etkinliklerin ilki olan Rasyonel Sayıları Tanıyorum etkinliği aşağıda Şekil 2' de verilmiştir.

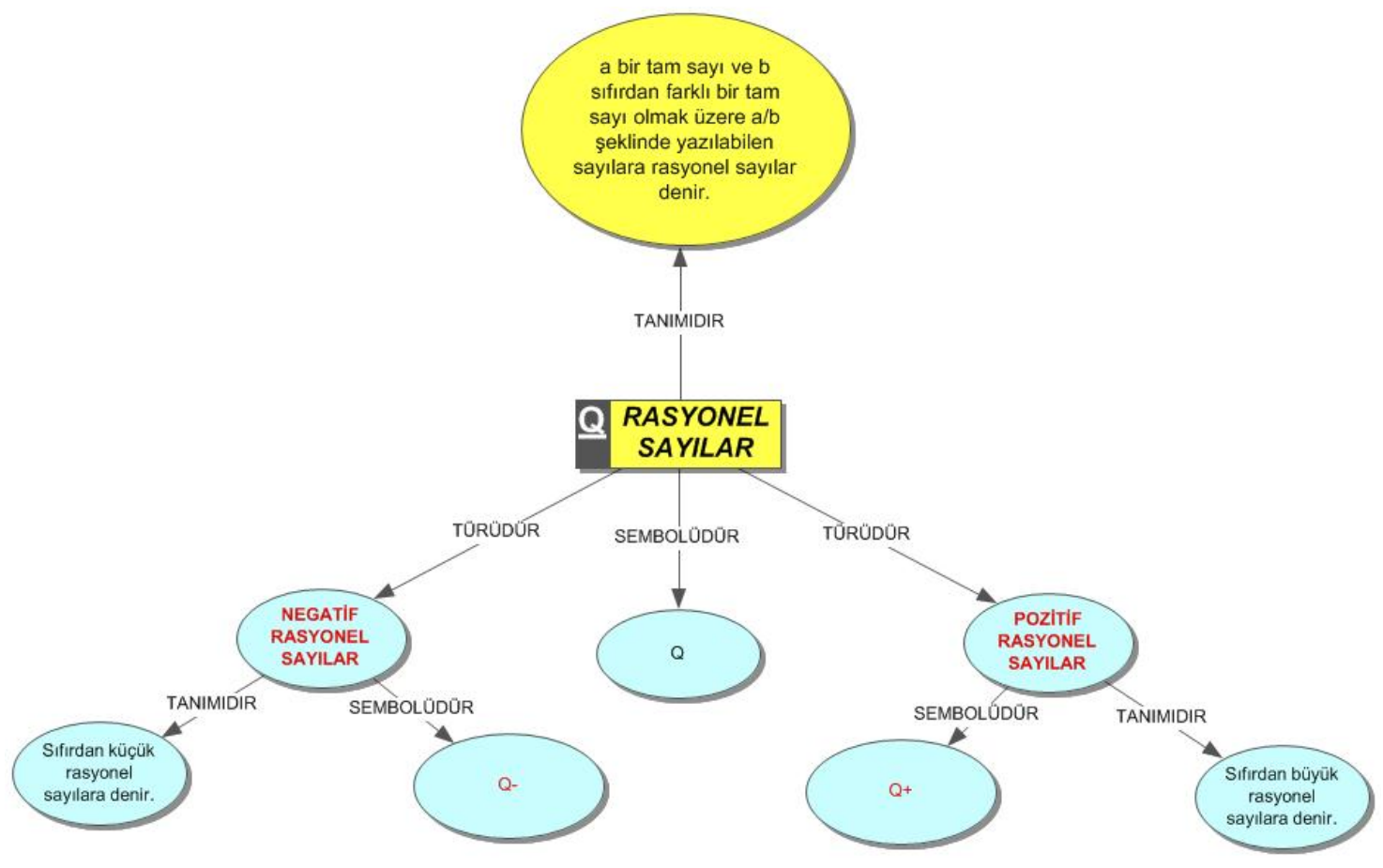

Şekil 2. Rasyonel Sayıları Tanıyorum Etkinliği

Şekil 2' deki Rasyonel Sayıları Tanıyorum Etkinliğinin hazırlanıp kullanılmasındaki amaç "Rasyonel sayıları tanır ve sayı doğrusunda gösterir. kazanımı doğrultusunda; "Rasyonel Sayı Nedir?", "Rasyonel Sayıların Sembolü Nedir?", "Rasyonel Sayıların Kaç Türü Vardır?" ve "Rasyonel Sayılar Sayı Doğrusunda Nasıl Gösterilir?" sorularına cevap vermektir. Rasyonel Sayılar konusunun öğrencilere kavratılması amacıyla hazırlanan kavram haritası öğrencilere ders girişinde verilip hazırbulunuşluluk seviyesini yüksek tutmak istenmiştir. Ayrıca ders sonunda hazırlanan kavram haritası, belirli kısımları silinip ÖlçmeDeğerlendirme amacıyla da kullanılabilir. 
Uygulanan etkinliklerin ikincisi olan Sıralaya bildiklerimizden misiniz? etkinliği aşağıda Şekil 3' de verilmiştir.

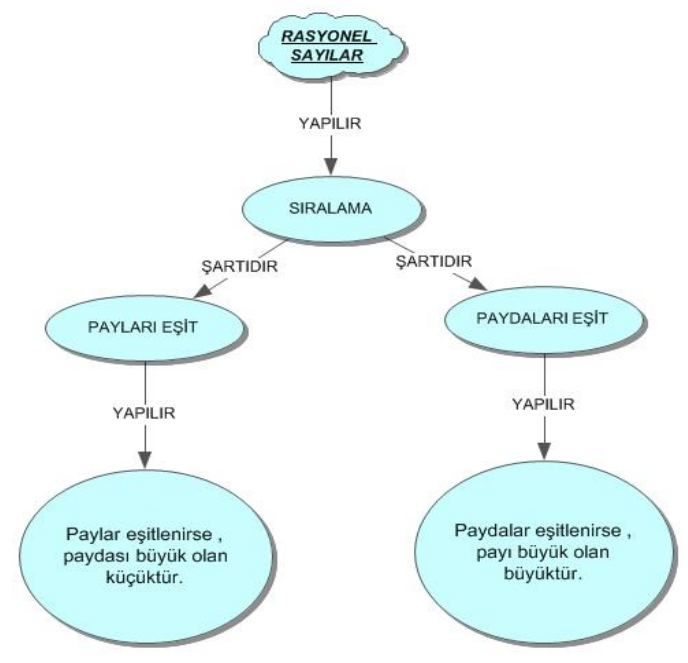

Şekil 3. Sıralaya bildiklerimizden misiniz? Etkinliği

Şekil 3' teki sıralaya bildiklerimizden misiniz? Etkinliğinin hazırlanıp kullanılmasındaki amaç "Rasyonel sayıları karşılaştırır ve sıralar." kazanımı doğrultusunda; "Rasyonel Sayılarda Sıralama Şartları Nelerdir?", "Payları Eşit Rasyonel Sayılarda Sıralama Nasıl Yapılır?" ve "Paydaları Eşit Rasyonel Sayılarda Sıralama Nasıl Yapılır?" sorularına cevap vermektir. Rasyonel Sayılarda Karşılaştırma ve Sıralama konusunun öğrencilere kavratılması amacıyla öğrencilere konu öncesi dağıtılıp göz gezdirmeleri ve derse hazır girmeleri sağlanır. İstenildiği takdirde açıklama balonları boş bırakılıp ders sonunda tekrar veya ÖlçmeDeğerlendirme amacıyla öğrencilerin kullanımına sunulabilir.

Uygulanan etkinliklerin üçüncüsü olan Topla-Çıkar Elde Var Rasyonel Sayı etkinliği aşağıda Şekil 4' te verilmiştir.

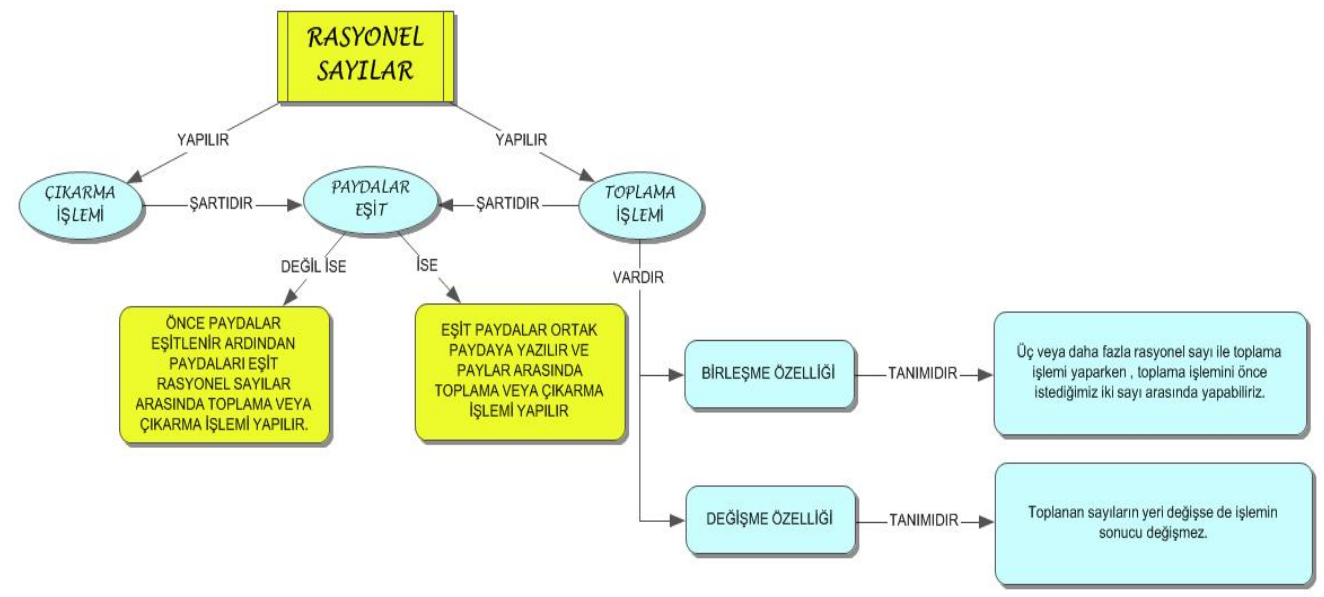

Şekil 4. Topla-Çıkar Elde Var Rasyonel Sayı Etkinliği

Şekil 4' teki Topla-Çıkar Elde Var Rasyonel Sayı etkinliğinin hazırlanıp kullanılmasındaki amaç "Rasyonel sayılarla toplama ve çıkarma işlemlerini yapar." kazanımı doğrultusunda; "Rasyonel Sayılarla Çıkarma İşlemi Nasıl Yapılır?", 
"Rasyonel Sayılarla Toplama İşlemi Nasıl yapılır? ve "Rasyonel Sayılarla Toplama İşleminin Özellikleri Nelerdir?" sorularına cevap vermektir. Rasyonel Sayılarda Toplama ve Çıkarma İşlemi konusunun öğrencilere kavratılması ve öğrencilere konu anlatımı öncesinde veya anlatım esnasında konunun pekişmesi için dağıtılabilir. Gerek görülmesi durumunda hazırlanan kavram haritası öğrencilere ÖlçmeDeğerlendirme, Hazırbulunuşluluk testi gibi formlarda kullanılabilir.

Uygulanan Etkinliklerin dördüncüsü olan Çarp-Böl Anla etkinliği aşağıda Şekil 5' te verilmiştir.
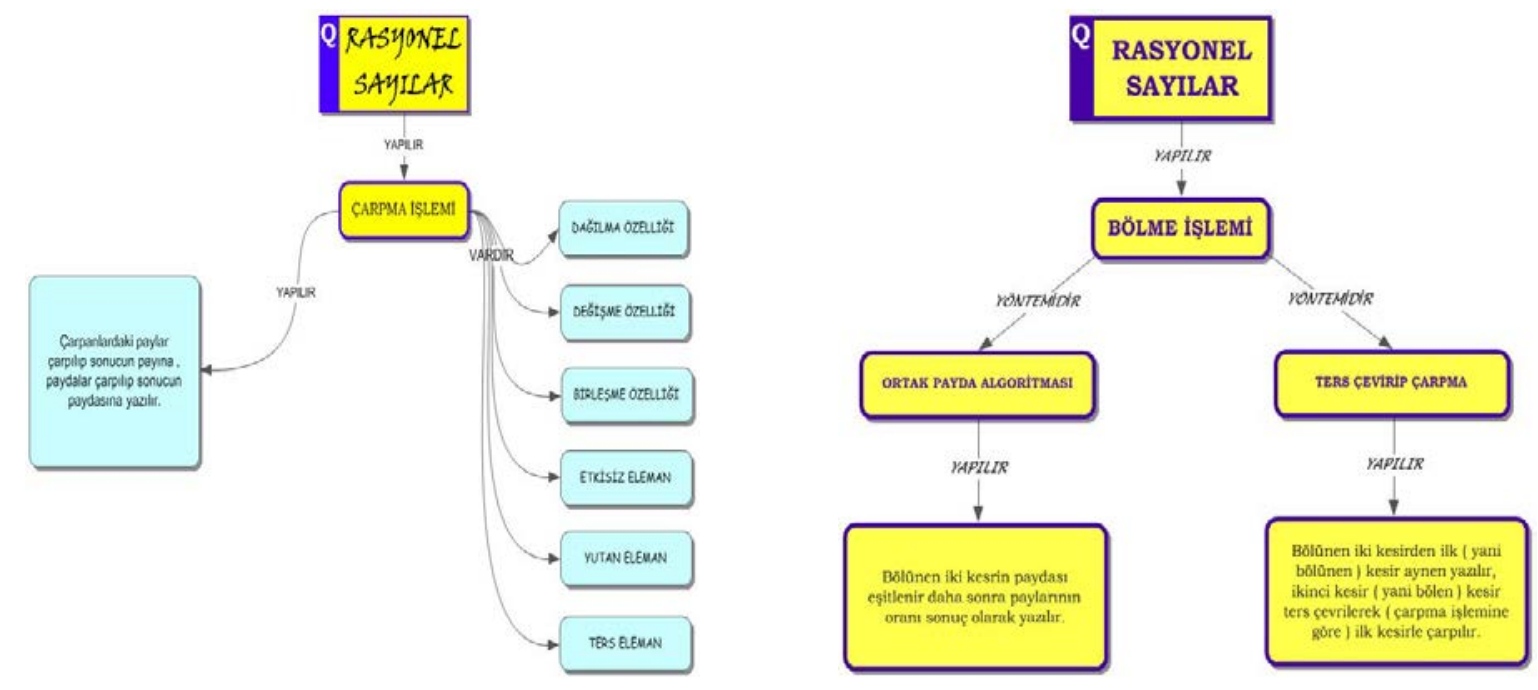

Şekil 5. Çarp - Böl Anla Etkinliği

Şekil 5' teki Çarp-Böl Anla Etkinliğinin hazırlanıp kullanılmasındaki amaç "Rasyonel sayılarla çarpma ve bölme işlemlerini yapar." kazanımı doğrultusunda; "Rasyonel Sayılarla Çarpma ve Bölme İşlemi Nasıl Yapılır?", "Rasyonel Sayılarda Çarpma İşleminin Özellikleri Nelerdir?" ve "Rasyonel Sayılarla Bölme İşleminde Hangi Yöntemler Vardır?” sorularına cevap vermektir. Rasyonel Sayılarla Çarpma ve Bölme İşleminin kavratılması ve öğrencilerin konu hakkında hazır bulunuşluklarının ölçülmesi amacıyla ders öncesi Ölçme-Değerlendirme formunda veya ders esnasında Yardımcı Kaynak formunda kullanılabilir. Öğrencilerin verdiği cevaplara bağlı olarak varsa hatalı veya eksik öğrenmeler düzeltilebilir ve anlamlı öğrenmeler oluşturulur.

Uygulanan etkinliklerin beşincisi olan İşlemlerim Adım Adım etkinliği aşağıda Şekil 6' da verilmiştir. 


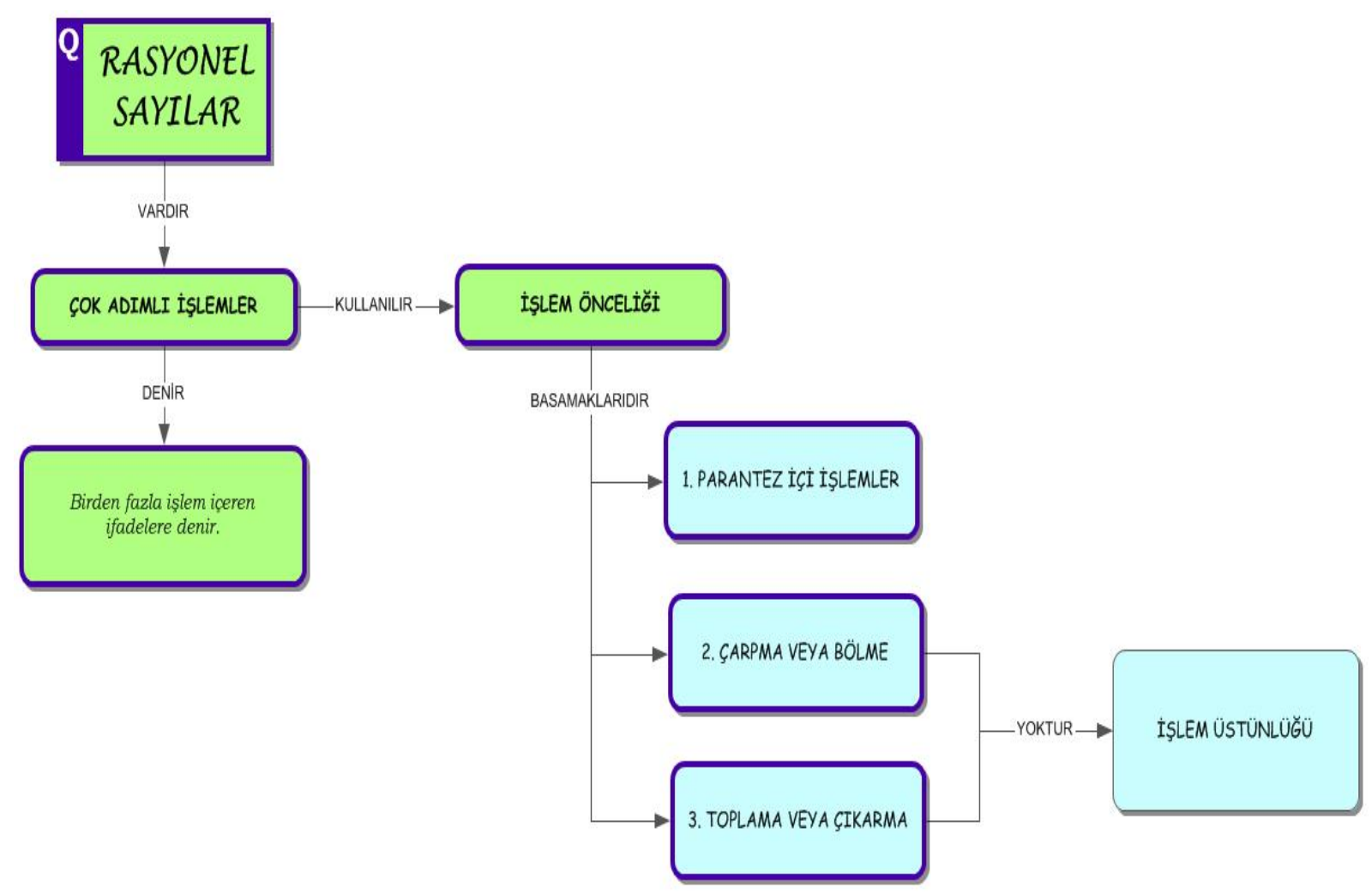

Şekil 6. İşlemlerim Adım Adım Etkinliği

Şekil 6'daki İşlemlerim Adım Adım etkinliğinin hazırlanıp kullanılmasındaki amaç "Rasyonel sayılarla çok adımlı işlemleri yapar. " kazanımı doğrultusunda; "Rasyonel Sayılarla Çok Adımlı İşlemler Nedir?", "Rasyonel Sayılarla Adım Adım İşlemler Nasıl Yapılır?" ve "Rasyonel Sayılarla Çok Adımlı İşlemlerde İşlem Önceliği Basamakları Nelerdir? sorularına cevap vermektir. Rasyonel Sayılarla Çok Adımlı İşlemler konusunun kavratıması amacıyla hazırlanan bu etkinlik öğrencilerin konuyu kavramalarına, eksik veya yanlış öğrenmelerin düzeltilmesine yardımcı olur.

Hazırlanan tüm bu etkinlikler Ön Değerlendirme Etkinliği, Yardımcı Kaynak, Konu Tekrar Etkinliği, Konu Özeti ve Ölçme-Değerlendirme Etkinliği olarak öğrencilerin kullanımına sunulabilir.

\section{Verilerin Toplanması}

Hazırlanan kavram haritaları etkinlikleri öğrencilere uygulanmış olup etkinliklere ve gerçekleştirilen öğrenime ilişkin öğrencilerin görüşlerini belirlemek amacıyla 5 adet açık uçlu sorudan oluşan görüş formu uygulanmıştır. Ayrıca öğretmenin görüşünü belirlemek amacıyla öğretmen ile mülakat yapılmıştır. Hazırlanan görüş formunda: i) Daha önce işlediğiniz Matematik dersi ile bu şekilde işlediğiniz Matematik Dersi arasındaki farklı yönleri yazınız. ii) Yeni sınıf ortamını nasıl buldunuz? Neden? iii) Bu etkinliklerden en çok hangisini beğendiniz? Neden? iv) Bu etkinlikleri yaparken sınıfınızda olumlu ya da olumsuz ne gibi değişiklikler olduğunu yazınız. Neden olumlu ya da olumsuz olduklarını belirtiniz. v) Kavram Haritası sizce sizlerin eğitimi için faydalı bir materyal midir? Neden? soruları kullanılmıştır. 
Ayrıca öğretmenle yapılan mülakatta kavram haritalarının uygulanması, dersin işlenişine katkısı ve öğretime etkisi konusundaki görüşleri alınmıştır. Öğretmenle yapılan mülakatta aşağıdaki temel sorular kullanılmıştır.

- Hocam dersin işlenişi sizce nasıldı?

- Peki, siz derslerinizde ne gibi etkinlikler kullanıyorsunuz? Ya da bu ve buna benzer etkinlikler kullanıyor musunuz?

- Kavram haritası tekniğiyle hazırlanan etkinlikleri nasıl buldunuz? Dersinize nasıl bir katkı sağladı?

- Kavram haritalarını Ölçme-Değerlendirme olarak mı yoksa ders içi yardımcı kaynak olarak mı kullanmak daha uygun olur?

- Sizce daha çok öğrenme gerçekleşmesi için yoruma dayalı kavram haritası mı yoksa ezber, bilgi isteyen kavram haritaları mı kullanılmalıdır?

- Peki, hocam, bundan sonraki meslek hayatınızda siz de ders işlenişlerinize kavram haritasını dâhil eder misiniz?

\section{Verilerin Analizi}

Öğrenci ve öğretmen görüşlerini belirlemek amacıyla toplanan nitel veriler betimsel analiz yöntemiyle analiz edilmiştir. Bu kapsamda toplanan veriler incelenerek araştırma amacı doğrultusunda kategoriler oluşturulmuş olup görüşlere ait bazı örnekler kodlanıp alıntılar yapılarak sunulmuştur. Betimsel çözümlemede toplanan veriler önceden oluşturulan temalara göre yorumlanmıştır. Elde edilen veriler, frekans belirtilerek çizelgeler biçiminde yazılmıştır. Bunun yanında öğrencilerin görüşlerinden doğrudan alıntılar yapılmıştır. Güvenirliğini sağlamak amacıyla, açık uçlu sorulara verilen yanıtlar araştırmacılar tarafından incelenerek "Görüş Birliği" ve "Görüş Ayrılığı" olan maddeler belirlenmiştir. Araştırmanın güvenirliğinde Miles ile Huberman'ın (1994) (Uzlaşma Yüzdesi) = [Na (Görüş Birliği)/ $\mathrm{Na}$ (Görüş Birliği) + Nd (Görüş Ayrılığı)] X 100 formülü yardımıyla hesaplanmış ve hesaplanma sonucunda uzlaşma değeri \% 92 bulunarak bu araştırmanın güvenilir olduğu kabul edilmiştir.

\section{Bulgular ve Yorum}

\section{Öğretmen ile Yapılan Mülakattan Elde Edilen Bulgular ve Yorumlar}

Kavram haritası ile yapılan ders sonrasında yapılan mülakatta Kavram Haritası şeklinde hazırlanan etkinliklerle alakalı olarak öğretmenden görüşler alınmıştır. Öğretmenin etkinlikler ve öğrenme ortam ve sürecine ilişkin görüşleri 3 tema altında toplanmıştır. Bu temalar aşağıdaki gibidir. görüşleri.

1. Kavram haritası kullanımının ders işleyişine etkisine yönelik öğretmen

2. Kavram haritasının kullanım şekline (Ölçme-değerlendirme/Öğretim) yönelik öğretmen görüşleri. 
3. Gelecek derslerde kavram haritası kullanıma yönelik öğretmen görüşleri.

Şimdi sırayla bu temalarla ilgili gerçekleşen görüşmeleri inceleyelim.

\section{Kavram haritası kullanımının ders işleyişine etkisine yönelik öğretmen görüşleri}

Araştırmacı: Kavram haritasıyla dersin işlenişi nasıldı?

Öğretmen: Eski ders işleyişiyle klyaslayacak olursak bu yeni ders işleyişi daha eğlenceli, zevkli ve gerçek anlamıyla farklıydı. Çocuklar Kavram Haritasını ilk kez kullanıyorlardı. Bu onlar için çok eğlenceli gözüküyordu. Alışılmışın dışında olan test tekniklerinin dışına çıkıldığı için sınıfın en iyi öğrencilerin de bile zorlanmalar oldu. Sınıfı 4 ' lü gruplara bölmek faydalı gözüküyordu. Öğrenciler arasında kaynaşma ve etkileşim gayet olumluydu.

Araştırmacı: Peki, siz derslerinizde ne gibi etkinlikler kullanıyorsunuz? Ya da bu ve buna benzer etkinlikler kullanıyor musunuz?

Öğretmen: Test ve soru çözümüne dayalı dersler işliyordum. Bunun sebebi ise var olan eğitim sistemidir. Şöyle açıklayabilirim aslında, gerçekçi olmak gerekirse öğrencilere 8. sınıfta uygulanan TEOG sebebiyle soru çözümüne daha çok teste dayalı ögretim yapmak mecburiyetinde kalıyorum.

Araştırmacı ve öğretmen görüşme kayıtlarında özetle öğretmen; Kavram haritası'nın çok faydalı olacağı görüşündedir. Öğrenciler için dersi daha eğlenceli daha dikkat çekici bir hâle getirmiştir. Öğretmen dersin işlenişine kavram haritasını eklemenin faydalı olduğunu savunmaktadır. Ama bunun var olan eğitim sisteminde özellikle matematik için uygulanmasının uygunsuz olduğunu düşünmektedir. Öğretmenin söylediklerinin ışığında eğitim sistemimiz her ne kadar Yapılandırmacı Yaklaşımı benimsemiş olsa da aslında tam anlamıyla bir Yapılandırmacı Yaklaşım değil de klasik Geleneksel Yaklaşım ile Yapılandırmacı Yaklaşım arası bir kimliktedir. $\mathrm{Bu}$ da bu tarz etkinlikleri Yapılandırmacı Yaklaşımdan dolayı yararlı, gerekli kılarken Geleneksel Yaklaşımdan dolayı uygulanması uygunsuz kılar.

Araştırmacı: Kavram haritası tekniğiyle hazırlanan etkinlikleri nasıl buldunuz? Dersinize nasıl bir katkı sağladı?

Öğretmen: Aldığım izlenime göre Kavram haritası çocuğun genel anlamda konuyu öğrenip öğrenmediğini, öğrenmenin hangi seviyede gerçekleştiği ve eksik, yanlış öğrenmelerin farkındalığı gibi başlıklarda fikir sahibi olmamızı sağladı. Bu da aslında bir nevi daha farklı bir ölçme tekniği olmuş oldu. Yani yeni bir sınav tarzımız olmuş oldu.

2. Kavram haritasının kullanım şekline (ölçme-değerlendirme/Öğretim) yönelik öğretmen görüşleri 
Araştırmacı: Cevabınıza binaen sadece matematik dersi için sormak istiyorum: Kavram haritalarını Ölçme-Değerlendirme olarak mı yoksa ders içi yardımcı kaynak olarak mı kullanmak daha uygun olur?

Öğretmen: Bu sorunuzu iki başlık altında cevaplamak istiyorum izninizle.

1. Ölçme-Değerlendirmedeki olumlu yanı yapmış olduğum klasik yazılı sınavlarında kavram haritası kadar kapsayıcı, genel geçer ve konuyu tümüyle ölçen bir yazılı kâğıdı hazırlayamamaktaydım. Bu da bu açıdan kavram haritasını ölçme - değerlendirme için uygun bir araç kılar.

2. Kavram haritası ders işlenişine eklendiği zaman öğrenmeler arası kopukluğu engellemektedir. Çünkü kavram haritası aslında konuya uzaktan, tümden bakabilme olanağı sunar. Ayrıca konu özeti yerine de geçtiği için ders içi yardımcı kaynak olarak etkili şekilde kullanılabilir.

Bu iki başlığın ışığında incelendiğinde kavram haritasını ölçme değerlendirme aracı veya yardımcı kaynak olarak kullanmak gayet başarılı bir çalışma olur.

Araştırmacı ve öğretmen arasında geçen diyaloglarda öğretmen; kavram haritalarının matematik dersi için gayet uygun bir materyal olduğunu söylemiştir. matematik dersinde kavram haritalarının öğrenmenin ne seviyede olduğu, yanlış öğrenmelerin tespitinde yararı olduğu belirtilmiştir. Kavram Haritalarının ders için en büyük artılarından biri konunun, olayın tüm etmenlerine aynı anda hâkim olan birey daha mantıklı, daha olumlu ve daha saf öğrenmeyi gerçekleştirir. Bu öğrenmenin gerçekleşmesi ve kalıcı olması için en önemli unsurdur.

Araştırmacı: Sizce daha çok öğrenme gerçekleşmesi için yoruma dayalı Kavram Haritası mı yoksa ezber, bilgi isteyen kavram haritaları mı kullanılmalıdır?

Öğretmen: Yoruma dayalı kavram haritaları hazırlamak daha mantıklıdır. sebep olarak ise ezber değil de mantığa oturtma yani öğrenci tarafından konunun mantığının kavranması esasına dayalı kavram haritaları kullanmak kalıcı öğrenmenin gerçekleşmesine daha çok katkı sağlar.

\section{Gelecek derslerde kavram haritası kullanıma yönelik öğretmen görüşleri}

Araştırmacı: Peki hocam, bundan sonraki meslek hayatınızda siz de ders işlenişlerinize kavram haritasını dâhil eder misiniz?

Öğretmen: Ortaokul kademesinde 5. , 6. ve 7. sınıflarda yapmayı düşünüyorum. Ama 8. Sınıflarda hem müfredat yoğunluğu hem de TEOG sebebiyle uygulamak pek olanaksız gözüküyor. Ayrıca hazır kavram haritaları internet ortamında pek bulunmamaktadır. Bu yüzden öğretmenin kendisinin hazırlaması gerekmektedir. İşte sıkıntının biri de budur. Çünkü Microsoft Excel, Microsoft Word ortamında kavram haritaları hazırlama araçlarına pek hâkim değilim ve hazırlamak için pek zamana da sahip değilim, çok zaman alır. Tüm bu olumsuz etmenlerden sıyrıldığımız zaman elbette ki tüm derslerimde kavram haritasını kullanırım. 
Araştırmacı: O zaman şunu sormak istiyorum hocam: Olumsuz etmenlerden sıyrılmak dediniz bunu nasıl sağlayabiliriz? Bunun için Milli Eğitim Bakanlığı'nın bir katkısı olabilir mi? Yoksa bireysel çözümlemeler mi gereklidir?

Öğretmen: Milli Eğitim Bakanlığı her yıl bastırdığı okul kitaplarına en iyi, en uygun kavram Haritalarını hazırlayıp ders sonu etkinlik olarak monte ederse hem öğretmenin yükü hafifler hem de eğitimin kalitesi kitlesel olarak artar.

Öğretmenin verdiği cevaplardan, kavram haritaları eğitim için olumlu şeylerdir ve öğretmen olarak kullanmayı düşünmekteyim. Ama bunun için önce Milli Eğitim Bakanlığı'nın kavram haritası tekniğiyle etkinlik kullanımını gündemine alması ve yaygınlaştırması gerekmektedir. İstenen ile verilen arasındaki uyuşmazlık var olduğu sürece yük öğretmenin sırtına kalmaktadır ve öğretmen bu yükü tamamen sırtlayamamaktadır. Kavram haritasının yaygınlaştırılması için Milli Eğitim Bakanlığı'nın kavram haritası ile hazırlanacak etkinlikleri ders kitaplarında kullanması daha hesaplıdır. Bunun yanı sıra öğretmenler için daha rahat kullanabilmeleri adına bilgisayar destekli kavram haritalarının öğretimine yönelik hizmet içi kurslar düzenlenebilir.

Öğretmen ile yapılan mülakat genel olarak değerlendirilecek olursa; Kavram haritasıyla hazırlanan etkinlikler öğrenmeyi daha kalıcı kılmaktadır. Bu etkinlikler öğrenmeyi geleneksel yaklaşım çizgisinden sıyırıp yapılandırmacı yaklaşım çizgisine yaklaştırmaktadır. Bu da eğitimin kalitesini arttırmaktadır. Kavram haritalarının hazırlanması ve uygulanmasının gerekli olduğu, öğrencilerde anlamlı öğrenmenin gerçekleşmesinin bir şartı olduğu, öğretmen için ders içi kontrole katkısının olduğu ve öğrencinin konuya bir bütün olarak bakabilmesine olanak tanıdığı için kapsayıcı olduğu anlaşılmaktadır. Ama sistemin tam anlamıyla yapılandırmacı yaklaşım çizgisinde olmamasından dolayı uygulanmasının biraz zor daha doğrusu zahmetli olduğu ortaya çıkmıştır.

\section{Öğrencilere Uygulanan Görüş Formundan Elde Edilen Bulgular}

Görüş Formunda öğrencilere 5 tane açık uçlu soru sorulmuştur. Öğrencilerin sorulara verdiği cevaplar betimsel analiz yöntemiyle değerlendirilmiştir. Görüş Formunun ilk sorusu olan "Daha önce işlediğiniz Matematik dersi ile bu şekilde işlediğiniz Matematik dersi arasındaki farklı yönleri yazınız." şeklindeki açık uçlu soruyu öğrencilerin tümü cevaplamıştır. Öğrencilerin vermiş olduğu cevaplar incelenip Tablo 1'de verilmiştir.

Tablo 1. Önceki İşleniş ile Yeni İşleniş Arasındaki Farklı Yönler Sorusuna Verilen Cevaplar

\begin{tabular}{lcc}
\hline İşlenişteki Farklılıklar & f & $\%$ \\
\hline Yeni işleniş daha eğlenceli & 3 & 13,04 \\
Yeni işleniş ile daha iyi anladığı & 5 & 21,74 \\
Yeni işlenişin daha kolay olduğu & 3 & 13,04 \\
Gruplar halinde ders işlemenin daha yararlı olduğu & 3 & 13,04 \\
Gruplar halinde ders işlemenin daha verimsiz olduğu & 1 & 4,35 \\
\hline
\end{tabular}




\begin{tabular}{lcc}
\hline Yeni işleniş ile dersin daha da zorlaştığı & 4 & 17,4 \\
Yeni işlenişin daha faydalı olduğu & 3 & 13,04 \\
İkisi arasında fark yok & 1 & 4,35 \\
\hline
\end{tabular}

Bu durum öğrencilerin geleneksel yaklaşım tarzıyla işlenen derslerden dolayı sıkılganlık ve derse karşı antipati gelişmiştir. Öğrencilerin büyük çoğunluğu yeni ders işleme tarzı hakkında olumlu fikir beyan etmişlerdir. Bunun nedeni eski sıkıcı ve öğretmen merkezli dersten yeni öğrenci merkezli etkileşimli derse geçiştir. Öğrenci, öğretmen merkezli derste pasif duruma düşer ve bilgi sadece öğretmenden alındığı için kopukluklar meydana gelmektedir. Burada bilgiyi tek kaynaktan yorumlamaya müsaade edilmeden ezberleme yöntemiyle aldığı için öğrenci dersten çabuk düşer ve bir aşamadan sonra öğrenilmiş gerçekleşir şeklinde yorumlanabilir.

Öğrenci görüşlerine ait bazı örnekler aşağıda sunulmuştur:

“Daha kolay ve keyifli oldu. Grupça daha iyi hep böyle olsun. ”(Ö15)

"Daha önce hiç böyle matematik dersi işlemedim. Bence bu matematik bize çok faydalı olacak. " (Ö20)

“Daha önce işlediğimiz matematik dersi daha kolaydı şimdi biraz farklı oldu ama zorlaştı. " (Ö17)

“Önce ile şimdi arasında bir fark görmedim. "(Ö4)

"Önceki derslerde daha sakindik şimdi ise daha aceleci ve arkadaşlarımızı geçme çabasındayız. Ama çok güzel. " (Ö11)

“Arkadaşlarım hiç bir şey bilmiyor. Grupça hiç güzel değildi. ”(Ö7)

Görüşme formunun ikinci sorusu olan " Yeni sınıf ortamını nasıl buldun? Neden? " şeklindeki açık uçlu soruyu öğrencilerin tümü cevaplamıştır. Öğrencilerin vermiş olduğu cevaplar incelenip Tablo 2 ' de sunulmuştur.

Tablo 2. Yeni ile Eski Sınıf Ortamı Arasındaki Farklar Sorusuna Verilen Cevaplar

\begin{tabular}{lcc}
\hline Sınıf Ortamındaki Farklılıklar & $f$ & $\%$ \\
\hline Yeni ortam daha faydalı & 10 & 43,48 \\
Grup yapmanın iyi olduğu ve etkileşimi arttırdığı & 6 & 20,09 \\
Yeni sınıf ortamının eskisine göre daha sessiz & 1 & 4,35 \\
Yeni ortam daha eğlenceli & 2 & 8,7 \\
Grup yerine bireysel etkinlik yapmak istediği & 2 & 8,7 \\
Grup içi konuşmadan dolayı rahatsız olduğu & 1 & 4,35 \\
İkisi arasında fark yok & 1 & 4,35 \\
\hline
\end{tabular}

Öğrenciler yeni sınıf ortamı hakkında genel olarak olumlu fikirler beyan etmişlerdir. Çoğunluk yeni ortamın onlara fayda sağlayacağı kanaatindedirler. Ayrıca bunun yanında eski sistem ile işlenen derste yüksek performans gösteren bazı öğrencilerin bu derste düşük performans gösterdiği, hırçınlaştığı gözlemlenmiştir. Bu 
durumun temel nedeni yeni sınıf ortamına adapte olamama ve grup içi seviye farkından dolayı üst seviyedeki öğrenciye daha fazla yük binmesidir.

Öğrenci görüşlerine ait bazı örnekler aşağıda sunulmuştur:

“Ben ve arkadaşım yapsaydık iyiydi ama diğer iki arkadaşım çok az yardım etti. " (Ö19)

"Güzel buldum. Bunun bize daha faydalı olduğunu düşünüyorum. Gruplara ayrılmamız daha güzel oldu. ”(Ö20)

“ Güzel buldum. Çünkü artık sınıfta kimse konuşmuyor. Daha iyi ders dinleyebiliyorum. " (Ö16)

“Çok güzel. Çünkü ders içi etkinlikler yaptık. ” (Ö6)

“ Iyi buldum. Çünkü arkadaşların neşesi yerinde. ” (Ö21)

“ Önceki ders daha iyi şimdiki kötü. Kurallara uymuyorlar. Herkes kavga ediyor. " (Ö17)

Görüşme formunun üçüncü sorusu olan "Bu etkinliklerden en çok hangisini beğendin? Neden?" şeklindeki açık uçlu soruyu öğrencilerin tümü cevaplamıştır. Öğrencilerin vermiş olduğu cevaplar incelenip Tablo 3 'te verilmiştir.

Tablo 3. Hangi Etkinliğin Daha Çok Beğenildiği Sorusuna Verilen Cevaplar

\begin{tabular}{llc}
\hline Beğenilen Etkinlikler & $\mathrm{f}$ & $\%$ \\
\hline Rasyonel Sayıları Tanıyorum Etkinliği & 1 & 4,35 \\
Sıralayabildiklerimizden $\quad$ misiniz? & 2 & 8,7 \\
Topla - Çıkar Elde Var Rasyonel Sayı & 3 & 13,03 \\
Çarp - Böl Anla Etkinliği & 3 & 13,03 \\
İşlemlerim Adım Adım Etkinliği & 7 & 30,43 \\
Tüm Etkinlikler & 2 & 8,7 \\
\hline
\end{tabular}

Öğrencilerin soruya verdiği cevaplara bakarak öğrencilerin cevaplarından daha az ezber bilgi isteyen etkinliklerin beğenildiği görülmektedir. İşlemlerim Adım Adım etkinliğinde öğrencilerden diğer etkinliklere göre daha az bilgi istenmiştir. Öğrenciler zihinlerini kullanabileceği ortamları sevmektedirler. Yorum yapabilecekleri, ezberden uzak oldukları soruların bulunduğu etkinliği beğenmeleri bu durumun bir göstergesidir. Çünkü matematiği zor kılan etmenlerden biri de formülü, kuralı veya yöntemi ezberlemektir. Öğrencileri bu durumdan uzaklaştırdığı için yoruma dayalı etkinlikler daha çok beğenilmiştir.

Öğrenci görüşlerine ait bazı örnekler aşağıda sunulmuştur:

“ IIlki. Çünkü insanın bir konu üzerinde kendi düşüncelerini yazmasının olumlu olduğunu düşündüğüm için. ” (Ö13)

“Topla - Çıkar Elde Var Rasyonel Sayı etkinliği beğendim. Çünkü boşlukları doldurmak çok kolaydı ve eğlenceliydi. ”(Ö1) 
"Rasyonel Sayıları Tanıyorum etkinliğini beğendim. Çünkü bildiğim her şeyi oraya yazdım ve konuyu ne kadar biliyorum öğrenmiş oldum " (Ö9)

“ IIlk yaptığımız çalışma. Çünkü anlamadığım şeyleri oraya yazdım ve hepsini öğreneceğim. " (Ö17)

Görüşme formunun dördüncü sorusu olan “ Bu etkinlikleri yaparken sınıfınızda olumlu ya da olumsuz ne gibi değişiklikler olduğunu yazınız. Neden olumlu ya da olumsuz olduklarını belirtiniz." şeklindeki açık uçlu soruyu öğrencilerin tamamı cevaplamıştır. Öğrencilerin vermiş olduğu cevaplar Tablo 4'te görülmektedir.

Tablo 4. Sınıfta Olumlu, Olumsuz Ne Gibi Değişiklikler Olduğu Sorusuna Verilen Cevaplar

\begin{tabular}{lcc}
\hline Sağladığı Katkılar & $f$ & $\%$ \\
\hline Aklı kullanmanın artması & 5 & 21,74 \\
Çalışmanın ve öğrenmenin arttığı & 4 & 17,4 \\
Öğretmenin ilgisinin arttığı & 2 & 8,7 \\
Daha eğlenceli bir ortamın oluştuğu & 2 & 8,7 \\
Eskiye nazaran daha çok içerik öğrendiği & 2 & 8,7 \\
Grupla çalışmanın olumlu olduğu & 3 & 13,04 \\
Gruplandırmanın olumsuz olduğu bireysel & 3 & 13,04 \\
Olumlu ölçme sağladığı & 2 & 8,7 \\
\hline
\end{tabular}

Öğrencilerin çoğu etkinlikler hakkında olumlu dönütler vermişlerdir. Ayrıca en can alıcı tespit ise 5 öğrencinin aklımızı daha çok kullanmamızı sağlıyor tespitidir. Kişi yeni bir durumla karşılaştığı zaman ilk olarak eskiden eksik olan maddelerin var olup olmadığını yeni durumda gözlemlemeye çalışır. Yani öğrenci eski ders işlenişinde aklını kullanmayı, yorum yapmayı pek kullanamamıştır. Bu durum da öğrencide anlamlı öğrenmeyi engeller.

Öğrenci görüşlerine ait bazı örnekler aşağıda sunulmuştur: (Ö20)

“ Grup olarak iyiyiz. Bunun bize olumlu bir fayda vereceğini düşünüyorum. ”

“ Olumlu. Zihnimiz daha iyi çalıştı. Çünkü aklımızı çalıştırıyor.”(Ö16)

“ Olumlu çünkü biz hepimiz çok eğlendik. ” (Ö2)

"Hiçbir olumlu şey yok çünkü bireysel olarak daha iyi anlıyordum. Grup olunca pek anlamamaya başladım. ” (Ö7)

"Sınıfta herkes aklını ve beynini kullandı. Tembel olan arkadaşlar bile cevap söyledi. " (Ö3)

"Evet, bizi çok iyi etkiledi. Beyniniz çalışmadığında bunları çözün beyniniz çalışır. "(Ö4)

Görüşme formunun beşinci sorusu olan "Kavram Haritası sence sizlerin eğitimi için faydalı bir materyal midir? Neden?” şeklindeki açık uçlu soruyu 
öğrencilerin tamamı cevaplamıştır. Öğrencilerin vermiş olduğu cevaplar incelenip Tablo 5 ' te verilmiştir.

Tablo 5. Kavram Haritası Sizler İçin Kullanılmalı mı? Neden? Sorusuna Verilen Cevaplar

\begin{tabular}{lcc}
\hline Kullanılmasını Gerektiren Nedenler & $\mathrm{f}$ & $\%$ \\
\hline Başarıyı arttırdığı & 2 & 8,7 \\
Gelişime yardımcı olduğu & 2 & 8,7 \\
Yararlı olduğu & 6 & 26,09 \\
Konuları daha iyi kavrattığı & 5 & 21,74 \\
Anlayarak yapmalarına yardımcı olduğu & 3 & 13,04 \\
Tekrar yaptırdığı & 2 & 8,7 \\
Dersi eğlenceli hale getirdiği & 1 & 4,35 \\
Daha kolay öğrettiği & 2 & 8,7 \\
\hline
\end{tabular}

Cevaplardan yola çıkarak öğrencilerin önceki derslerde en çok çektikleri sıkıntılar kavramama, anlamama ve yararlı görmemektir. Hazırlanan kavram haritalarıyla öğrencilerin çekmiş olduğu kavrama, anlama sıkıntıları giderilmiş olup eğitim daha yararlı duruma getirilmiş olur. Öğrenci görüşlerine ait bazı örnekler aşağıda sunulmuştur:

“Evet, bilgilerimizi pekiştiriyoruz.” (Ö23)

“Evet, çünkü öğrenmemiz daha kolay olur. ” (Ö22)

“ Bence faydalı bir materyaldir. Çünkü hem öğretici hem de eğlenceli bir şeydir. " (Ö21)

"Evet. Çünkü daha çok bilgi öğrendik ve ilerde bilgi yarışmasında da başarılı olabiliriz. " (Ö11)

“Evet çünkü herkes anlayarak ve eğlenerek yapıyor. ” (Ö18)

“Evet çünkü daha iyi anlamamızı sağladı. ” (Ö7)

"Evet çünkü kavram haritası ile işlediklerimizi daha iyi anladık ve hatırladık. " (Ö16)

“Evet çünkü daha fazla ayrıntılı öğreniyoruz. ”(Ö14)

“Evet konuları pekiştirdim. Çok güzeldi. ” (Ö15)

Genel olarak öğrenciler kavram haritaları hakkında olumlu fikir belirtmişlerdir. Düşüncesi olumsuz olan öğrenciler ise daha çok ilk defa kavram haritası destekli matematik dersi işlediklerinden bu durumun onları zorlamasını sebep göstermişlerdir.

\section{Sonuç ve Tartışma}

Öğrencilere matematiği kavratmanın, anlamlandırmanın en önemli yolu eğitimi geleneksel, öğretmenin ders sonuna kadar anlattığı, öğrencinin pasif, sadece dinleyen olduğu öğretimden kurtarıp öğrenci-öğrenci, öğrenci-öğretmen etkileşimini 
arttırmaya çalışmaktır. Öğretmen, eğitimi veren değil de öğretim sürecini planlayan, öğretimi rehabilite eden role sahip olması gerekmektedir. Bu role sahip olan öğretmen ders kontrolünde, verilen eğitimin kalitesinde ve eğitimde istenilen sonuca varma konusunda istenileni yapacak seviyeye ulaşmış demektir. Bilgi teoriktir ama öğretim pratiktir. Geleneksel yaklaşımı benimseyen öğretmen teoride iyi olsa bile pratikte tam istenilen seviyeye ulaşması intimali çok düşüktür.

Kavram haritasının rasyonel sayılar konusunun öğretiminde kullanımı hakkında öğretmen görüşü değerlendirildiğinde, kavram haritalarının öğrencilerin kendi bilgilerini yapılandırmasından dolayı geleneksel ortamdan farklı bir öğrenme ortamı oluşturduğu, öğretici bir özelliğe sahip olduğu, anlamlı öğrenmelerine yardımcı olduğu ve dersi daha eğlenceli bir hale getirdiği görüşünü taşıdığı ortaya çıkmıştır. Kavram haritalarını ders sürecinde kullanımının faydalı olduğu, ders sürecinde de kullanmayı düşündüğü ortaya çıkmıştır. Benzer şekilde Tuluk (2015) çalışmasının sonucunda kavram haritalarının bir konunun öğretiminde ve öğrenme sürecini kontrol etmede, kavram yanılgılarını belirlemede, öğrenciyi tanımada kullanılabilecek etkili bir yaklaşım olduğunu ortaya koymuştur. Bu bağlamda Milli Eğitim Bakanlığı'nın kavram haritası tekniğiyle etkinlik kullanımını gündemine alması ve yaygınlaştırması gerekmektedir. İstenen ile verilen arasındaki uyuşmazlık var olduğu sürece yük öğretmenin sırtına kalmaktadır. Kavram haritasının yaygınlaştırılması için Milli Eğitim Bakanlığı'nın kavram haritası ile hazırlanacak etkinlikleri ders kitaplarında kullanması daha uygun olacaktır.

Araştırmamızdan elde edilen diğer bir sonuç, kavram haritalarının matematik dersi için gayet uygun bir materyal olduğu, matematik dersinde kavram haritalarının öğrenmenin ne seviyede olduğu, yanlış öğrenmelerin tespitinde yararlı olduğu sonucuna ulaşılmıştır. Çalışmanın sonucunda öğrencilerin görüşleri değerlendirildiğinde, öğrencilerin kavram haritaları yardımıyla yapılan öğrenme sürecine ilişkin olarak olumlu görüş içinde oldukları sonucuna varılmıştır. Ancak öğrencilerin çoğunluğu bu şekildeki öğrenme ortamının onlara fayda sağlayacağı kanaatinde iken eski sistem ile işlenen derste yüksek performans gösteren çok az bir öğrenci bu derste düşük performans gösterdiği ve hırçınlaştığı gözlemlenmiştir. Bu durumun temel nedeni yeni sınıf ortamına adapte olamama ve grup içi seviye farkından dolayı üst seviyedeki öğrenciye daha fazla yük binmesidir. Nitekim Çimer \& Çimer (2002) çalışmalarında, öğrencilerin çoğunluğunun kavram haritası oluşturmayı sıkıcı bulduğunu ve eğlenceli olmadığını belirttiklerini ifade etmişlerdir. Araştırmamızdan elde edilen bu sonuç, Çimer \& Çimer (2002) çalışmasının bu yönüyle çelişmektedir. Yeni oluşturulan sınıf ortamı hem öğrenciler arası etkileşimi arttırmış hem de öğretmenin sınıf hâkimiyetine katkı sağlamıştır. Öğretmen öğrencilerin öğrenmelerine daha kolay rehberlik yapabilmekte ve yanlış öğrenmelere hızlı engel olabilmektedir.

Bunun yanında elde edilen diğer bir sonuç olarak kavram haritaları yardımıyla hazırlanan etkinliklerden öğrencilerin özellikle yoruma dayalı olana etkinlikleri 
beğendikleri anlaşılmaktadır. Bu şekilde işlenen derste öğrencilerin yaparak ve yaşayarak öğrendiklerini, derse aktif olarak katılarak kendi bilgilerini akranlarıyla paylaşarak yapılandırdıkları, daha önce yaşamış oldukları anlama sıkıntılarının ortadan kaldırılarak daha yararlı olduğu görüşünü taşıdıkları tespit edilmiştir. Kavram haritası tekniği ile hazırlanmış etkinliklerde öğrenciler anlamadıkları ya da anımsayamadıkları noktaları tamamlamak için bir rehber ararlar. En iyi rehber öğretmendir. Öğretmenin yapacağı rehberlik, yanlış ve eksik öğrenmelerin önüne geçecektir. Rehberlik öğrencinin özgüven duygusunu yükseltir yapabilirliğe olan inancını arttırır. Öğrencilerin matematiğe karşı var olan ön yargılarını aşmakta rehberlik çok önemli bir yöntemdir. Bu amaca hizmet edecek materyallerden biride kavram haritasıdır.

$\mathrm{Bu}$ çalışmanın sonuçlarına bağlı olarak kavram haritasının matematik öğretimine etkisini arttırmak için şu önerilerde bulunulmuştur.

$\checkmark$ MEB'in dağıttığı ders ve çalışma kitaplarında kavram haritalarına dayalı görsellere ve etkinliklere yer vermelidir.

$\checkmark$ Kavram haritalarıyla etkinlikleri sınıf ortamında uygularken ezber bilgi isteyen etkinlikler yerine daha çok yorum şansı bulunan etkinliklere yer verilmelidir.

$\checkmark$ Öğretmenler için kavram haritalarını derslerinde daha rahat kullanabilmeleri için bilgisayar destekli kavram haritalarının (İnspration, Kidsparation gibi) öğretimine yönelik hizmet içi kurslar düzenlenebilir.

$\checkmark$ Bilgisayar destekli programlar yardımıyla hazırlanan kavram haritalarının sınıf ortamında kullanılabilirliğine ilişkin araştırmalar yapılabilir.

$\checkmark$ Matematik dersinde zorlanılan diğer konularda da kavram haritalarının kullanımına yönelik araştırmalar yapılmalıdır.

Öğrencilerin bilgiyi anlamlandırmasına, verilen bilgiyi ezberlemek yerine mantığını kavramaya ve soyut matematiği somutlaştırmasına yardımcı olabilmek için kavram haritalarından yararlanılabilir.

\section{Kaynaklar}

Altıntaş, G. \& Altıntaş, U. (2008). İlköğretim 5. sınıf sosyal bilgiler dersinde "kavram haritası" kullanımının öğrenci akademik başarısı üzerindeki etkisi. Kastamonu Eğitim Fakültesi Dergisi, 16 (1), 61-66.

Anderson-Inman, L. \& Ditson, L. (1999) Computer-based cognitive mapping: a tool for negotiating meaning, Learning and Leading Technology, 26, 6-13.

Atay, S. \& Karabacak, Ü. (2012). Care plans using concept maps and their effects on the critical thinking dispositions of nursing students. International Journal of Nursing Practice, 18 (3), 233-239. 
Birgin, O. \& Gürbüz, R. (2009). İlköğretim II. Kademe öğrencilerinin rasyonel sayılar konusundaki işlemsel ve kavramsal bilgi düzeylerinin incelenmesi. Uludağ Üniversitesi Eğitim Fakültesi Dergisi, 22 (2), 529-550.

Chiou, C. C., Tien, L. C., \& Lee, L. T. (2015). Effects on learning of multimedia animation combined with multidimensional concept maps. Computers \& Education, 80, 211-223.

Çömek, A., Akınoğlu, O., Elmacı, E., \& Gündoğdu, T. (2016). Fen eğitiminde kavram haritaları kullanımının akademik başarı ve tutuma etkisi. International Journal of Human Sciences, 13 (1), 348-363.

Durmuş, S. (2005). Rasyonel sayılarda bölme işlemini ilköğretim öğrencilerin algılayışları. Sakarya Üniversitesi Eğitim Fakültesi Dergisi, 9, 97- 109.

Ekiz, D. (2009). Bilimsel araştırma yöntemleri. Ankara: Anı Yayıncılık.

Evrekli, E., İnel, D. \& Balım, A. G. (2012). Kavram ve zihin haritası kullanımının öğrencilerin kavramları anlama düzeyleri ile fen ve teknolojiye yönelik tutumları üzerindeki etkileri. Abant İzzet Baysal Üniversitesi Eğitim Fakültesi Dergisi. 12(1), 229-250

Gürbüz, R. (2006). Olasılık Konusunun Öğretiminde Kavram Haritaları. Yüzüncü YıI Üniversitesi, Eğitim Fakültesi Dergisi, 3(2), 133-151.

Gürbüz, R. ve Birgin, O. (2008). Farklı Öğrenim Seviyesindeki Öğrencilerin Rasyonel Sayıların Farklı Gösterim Şekilleriyle İşlem Yapma Performanslarının Karşılaştırılması. Pamukkale Üniversitesi Eğitim Fakültesi Dergisi, 23(1), 8594.

Hay, D. B. \& Proctor, M. (2015). Concept maps which visualise the artifice of teaching sequence: Cognition, linguistic and problem-based views on a common teaching problem. Knowledge Management \& E-Learning, 7(1), 3655.

Huang, H. S., Chiou, C. C., Chiang, H. K., Lai, S. H., Huang, C. Y. \& Chou, Y. Y. (2012). Effects of multidimensional concept maps on fourth graders' learning in web-based computer course. Computers \& Education, 58 (3), 863-873.

İngeç, Ş.K. (2008). Kavram haritalarının değerlendirme aracı olarak fizik eğitiminde kullanılması. Hacettepe Üniversitesi Eğitim Fakültesi Dergisi, 35, 195-206

Kaptan, F. (1998). Fen öğretiminde kavram haritası yönteminin kullanılması. Hacettepe Üniversitesi Eğitim Fakültesi Dergisi, 14, 95-99.

Kaşlı, A.F., Aytaç, V. \& Erdur, G. (2001), Kavram haritalama. Ege Eğitim Dergisi, 1(1), 127-136.

Merenluoto, K. \& Lehtinen, E. (2004). Number concept and conceptual change: outlines for new teaching strategies. Learning and Instruction, 14, 519-534. 
Novak, J. D. \& Cañas, A. J. (2008) The theory underlying concept maps and how to construct and use them. technical Report. Institute for Human and Machine Cognition, Pensacola.

Novak, J. \& Gowin, D.B. (1984). Learning how to learn, Cambridge: Cambridge University Press.

Oğraş, A. \& Bozkurt, A.(2011). Kavram haritası ve vee diyagramı kullanımının ilköğretim 7. sınıf matematik öğretiminde öğrenci başarısına etkisi. Gümüşhane Üniversitesi Sosyal Bilimler Elektronik Dergisi, 3, 1-13.

Orhun, N. (2007). Kesir işlemlerinde formal aritmetik ve görselleştirme arasındaki bilişsel boşluk. Inönü Üniversitesi Eğitim Fakültesi Dergisi, 8(14), 99-111.

Sellmann, D., Liefländer, A. K. \& Bogner, F. X. (2015). Concept maps in the classroom: a new approach to reveal students' conceptual change. The Journal of Educational Research, 108 (3), 250-257.

Stafylidou, S. \& Vosniadou, S. (2004). Students' understanding of numerical value of fractions: a conceptual approach. Learning and Instruction, 14, 503-518.

Şahin, F. (2001). Öğretmen adaylarının kavram haritası yapma ve uygulama hakkındaki görüşleri, Pamukkale Üniversitesi Eğitim Fakültesi Dergisi, 10, 1225.

Şen, A. İ., \& Aykutlu, I. (2008). Using concept maps as an alternative evaluation tool for students' conceptions of electric current. Eurasian Journal of Educational Research, 31, 75-92.

Torre, D. M., Durning, S. J. \& Daley, B. J. (2013). Twelve tips for teaching with concept maps in medical education. Medical Teacher, 35(3), 201-208.

Tuluk, G. (2015). Ortaokul matematik öğretmeni adaylarının açı kavramına ilişkin oluşturdukları kavram haritalarının değerlendirilmesi. Türk Bilgisayar ve Matematik Eğitimi Dergisi, 6 (2), 323-337.

Vamvakoussi, X. \& Vosniadou, S. (2004). Understanding the structure of the set of rational numbers: a conceptual change approach, Learning and Instruction, 14, 453-467.

Won, M., Ley, S. \& Treagust, D. (2013). Concept maps as a diagnostic tool for teaching and learning physics in the $44^{\text {th }}$ Annual Conference of the Australasian Science Education Research Association, 2-5 Temmuz. Wellington, NZ: ASERA. 